REVIEW

\title{
Use of diuretics in cardiovascular disease: (2) hypertension
}

\author{
S U Shah, S Anjum, W A Littler
}

Postgrad Med J 2004;80:271-276. doi: 10.1136/pgmi.2003.010843

Hypertension is a common condition associated with increased mortality and multiple morbidities. Evidence based management of hypertension is known to improve both the short term and the long term outcomes in patients with this condition. There are several general measures and pharmacological agents that are known to treat hypertension adequately. Diuretics, in particular low dose thiazide and thiazide-like diuretics, are widely used in the treatment of hypertension. They have excellent outcome data and high safety and low side effects profiles. In this article, the physiology, pharmacological actions, side effects, and outcome data of the use of diuretics in hypertension are reviewed. In addition, the effective use of diuretics in the management of hypertension is discussed.

See end of article for authors' affiliations

\section{Correspondence to:} Dr Saeed Ullah Shah, 17 South Street, Harborne, Birmingham B17 ODB, UK; saeedshah@miranshah. freeserve.co.uk

Submitted 7 June 2003 Accepted

5 November 2003
D iuretics have been used effectively to treat millions of hypertensive patients during the past four decades. They reduce both systolic and diastolic blood pressures in the great majority of hypertensive patients. They are as effective as most other antihypertensive drugs. ${ }^{12}$ Diuretics administered alone or in combination with other agents form the basis of therapy for the majority of hypertensive patients. ${ }^{3}$ A thiazide is the usual choice, generally in combination with other antihypertensive agents. ${ }^{4}$ Loop diuretics are usually reserved for patients with renal insufficiency, resistant hypertension, or heart failure. Diuretics are prescribed for patients with hypertension because of, firstly, their efficacy, low cost, and low side effects profile; secondly, their synergistic effect when combined with other antihypertensive agents; thirdly, the fact that they counteract salt and fluid retention caused by other antihypertensive agents; and, fourthly, their usefulness in patients with heart failure.

\section{CLASSIFICATION AND MECHANISM OF ANTIHYPERTENSIVE ACTION}

Diuretics useful in the treatment of hypertension may be divided into four major groups according to their primary site of action within the renal tubule, starting in the proximal portion and moving to the collecting duct.5 They include agents acting on the proximal tubule, such as carbonic anhydrase inhibitors, which have limited antihypertensive efficacy; loop diuretics; thiazides and related sulphonamide compounds; and potassium sparing agents (table 1 ).

A common feature of all diuretics is their natriuretic action, which leads to a decrease in total body sodium. The most potent diuretics (frusemide, bumetanide, and ethacrynic acid) decrease sodium resorption in the thick ascending loop of Henle by interfering with the $\mathrm{Na}-\mathrm{K}^{+}-$ $2 \mathrm{Cl}^{-}$cotransport system located at the apical membrane of the renal tubule. These diuretics act at a site where a large quantity of sodium is normally reabsorbed. Therefore, the amount of urinary sodium excretion and accompanying fluid loss can be enhanced considerably with these agents by increasing the dose. Loop diuretics are effective even in patients with severely impaired renal function. Thiazides, metolazone, and indapamide inhibit sodium resorption in the early portion of the distal convoluted tubule. These diuretics inhibit the apical $\mathrm{Na}^{+}-\mathrm{Cl}^{-}$cotransport system. Only a small fraction of the filtered sodium is normally reabsorbed at this site, which explains the limited natriuretic activity of this class of diuretics. The dose-response curves for these diuretics are rather flat. Furthermore, the natriuretic effect of thiazides and to some extent indapamide is lost when the glomerular filtration rate (GFR) is reduced below about $40 \mathrm{ml} / \mathrm{min}$, whereas metolazone is still active down to a GFR of about $20 \mathrm{ml} / \mathrm{min}$.

In the distal convoluted tubule and in the cortical collecting duct, sodium is transported at the apical level of the tubular cell through a sodium channel. Sodium is then exchanged for potassium at the basal membrane as a result of the activity of $\mathrm{Na}^{+}-\mathrm{K}^{+}$ATPase. The activity of this enzyme is enhanced by aldosterone, the mineralocorticoid hormone secreted by the adrenal zona glomerulosa. Loop diuretics, thiazides, and metolazone, as well as triamterene, amiloride, and spironolactone, act in the late portion of the distal convoluted tubule and the cortical collecting duct. Triamterene and amiloride have weak natriuretic action. Spironolactone is a competitive antagonist of aldosterone and, consequently, inhibits pump activity. Amiloride and triamterene block the apical sodium transport. The elimination of potassium is reduced by diuretics acting in the most distal portions of the nephron because of decreased sodium-potassium exchange. In contrast, loop diuretics and diuretics acting in the early distal convoluted tubule increase kaliuresis and tend to cause hypokalaemia. This is mainly because these agents enhance the delivery of sodium downstream and subsequently accentuate the sodium-potassium exchange. As a result, more sodium is available for resorption in the late distal convoluted tubule and the cortical collecting duct.

Abbreviations: $A C E$, angiotensin converting enzyme; $\mathrm{ARB}$, angiotensin receptor blocker; $\mathrm{Cl}$, confidence interval; GFR, glomerular filtration rate 


\begin{tabular}{|c|c|c|c|c|c|c|c|}
\hline Class & Example(s) & Mechanism(s) & $\begin{array}{l}\text { Optimal dose } \\
\text { (mg) }\end{array}$ & $\begin{array}{l}\text { Duration of } \\
\text { action }(\mathrm{h})\end{array}$ & Advantages & Disadvantages & Comments \\
\hline \multirow[t]{4}{*}{ Thiazides } & $\begin{array}{l}\text { Hydro- } \\
\text { chlorothiazide }\end{array}$ & Natriuresis & $\begin{array}{l}12.5-25.0 \mathrm{mg} \\
\text { once daily }\end{array}$ & $6-12$ & $\begin{array}{l}\text { Potentiates other } \\
\text { antihypertensives }\end{array}$ & Hypokalaemia & $\begin{array}{l}\text { Especially effective in } \\
\text { black patients, the } \\
\text { obese, } \\
\text { and the elderly }\end{array}$ \\
\hline & Chlorothiazide & \multirow[t]{3}{*}{ Vasodilatation } & $\begin{array}{l}125-250 \mathrm{mg} \\
\text { once daily }\end{array}$ & $6-12$ & & Hyperuricaemia & \\
\hline & Bendrofluazide & & $\begin{array}{l}1.25-2.5 \mathrm{mg} \\
\text { once daily }\end{array}$ & $6-12$ & Low cost & Hypercholesterolaemia & \\
\hline & Trichlorothiazide & & $\begin{array}{l}1-2 \mathrm{mg} \\
\text { once daily }\end{array}$ & $6-12$ & $\begin{array}{l}\text { Proven end organ } \\
\text { efficacy }\end{array}$ & Hyperglycaemia & $\begin{array}{l}\text { Mediated via } \\
\text { low } \mathrm{K}^{+}\end{array}$ \\
\hline \multirow[t]{3}{*}{$\begin{array}{l}\text { Thiazide } \\
\text { related }\end{array}$} & Chlorthalidone & Natriuresis & $\begin{array}{l}12.5-25.0 \mathrm{mg} \\
\text { once daily }\end{array}$ & $6-12$ & Lasts $24-48 \mathrm{~h}$ & Hypokalaemia & $\begin{array}{l}\text { Especially effective in } \\
\text { black patients, the } \\
\text { obese, } \\
\text { and the elderly }\end{array}$ \\
\hline & Indapamide & \multirow[t]{2}{*}{ Vasodilatation } & $\begin{array}{l}1.5-2.5 \mathrm{mg} \\
\text { once daily }\end{array}$ & $16-36$ & $\begin{array}{l}\text { Works even if GFR is } \\
\text { below } 50 \mathrm{ml} / \mathrm{min}\end{array}$ & Hyperuricaemia & \\
\hline & Metolazone & & $\begin{array}{l}0.5-2.5 \mathrm{mg} \\
\text { once daily }\end{array}$ & $18-25$ & $\begin{array}{l}\text { Works even if GFR is } \\
\text { below } 50 \mathrm{ml} / \mathrm{min}\end{array}$ & Hypercholesterolaemia & \\
\hline \multirow[t]{3}{*}{$\begin{array}{l}\mathrm{K}^{+} \\
\text {sparing }\end{array}$} & Spironolactone & \multirow[t]{3}{*}{ Natriuresis } & $\begin{array}{l}25-100 \mathrm{mg} \\
\text { once daily }\end{array}$ & $3-5$ days & Spares $\mathrm{K}^{+}$ & Gynaecomastia & $\begin{array}{l}\text { Higher doses in primary } \\
\text { hyperaldosteronism }\end{array}$ \\
\hline & Triamterene & & $\begin{array}{l}25-50 \mathrm{mg} \\
\text { once daily or } \\
\text { twice daily }\end{array}$ & $8-12$ & $\begin{array}{l}\text { No effect on glucose, } \\
\text { uric acid, or lipid }\end{array}$ & $\begin{array}{l}\text { Little hypotensive } \\
\text { effect on its own }\end{array}$ & $\begin{array}{l}\text { Use with caution in } \\
\text { patients with renal } \\
\text { dysfunction }\end{array}$ \\
\hline & Amiloride & & $\begin{array}{l}5 \mathrm{mg} \text { once } \\
\text { daily }\end{array}$ & $6-24$ & & & \\
\hline \multirow[t]{3}{*}{ Loop } & Frusemide & \multirow[t]{3}{*}{ Natriuresis } & $\begin{array}{l}10-40 \mathrm{mg} \\
\text { twice daily }\end{array}$ & $4-5$ & \multirow[t]{3}{*}{ More potent diuresis } & Hypokalaemia & \multirow[t]{3}{*}{$\begin{array}{l}\text { Less effective } \\
\text { antihypertensive } \\
\text { effects despite greater } \\
\text { diuresis }\end{array}$} \\
\hline & Bumetanide & & $\begin{array}{l}0.5 \mathrm{mg} \\
\text { twice daily }\end{array}$ & $4-5$ & & Hyperuricaemia & \\
\hline & $\begin{array}{l}\text { Ethacrynic } \\
\text { acid }\end{array}$ & & $\begin{array}{l}25 \mathrm{mg} \\
\text { once daily }\end{array}$ & $4-8$ & & Hypercholesterolaemia & \\
\hline
\end{tabular}

The exact mechanism of antihypertensive action of diuretics is not known. ${ }^{6}$ All diuretics initially lower the blood pressure by increasing urinary sodium excretion and reducing plasma volume, extracellular fluid volume, and cardiac output. Within six to eight weeks, the plasma volume, extracellular fluid volume, and cardiac output return towards normal. Beyond this point, the lower blood pressure is related to a decline in peripheral resistance, thereby improving the underlying haemodynamic defect of hypertension. ${ }^{7}$ The vasodilatory effect of diuretics is probably related to the loss of sodium and water from the vessel wall. ${ }^{8}$ In addition, some of the vasodilatory action is mediated through the release of prostacyclin and endothelial derived relaxing factor. ${ }^{9}$ The mechanism responsible for the lowered peripheral resistance may also involve activation of the potassium channel. ${ }^{10}$

\section{SIDE EFFECTS}

The side effects of high dose diuretic therapy are usually not overly bothersome, but the hypokalaemia, hypercholesterolaemia, hyperinsulinaemia, and worsening of glucose tolerance that often accompany prolonged high dose diuretic therapy raise concerns about the long term benignity of this treatment (table 2). However, lower doses are usually just as potent as higher doses in lowering the blood pressure and are less likely to induce metabolic changes. ${ }^{1}$

\section{DIURETICS IN HYPERTENSION \\ Outcome data}

A large number of primary prevention trials have found strong and consistent support for endorsing diuretics, in particular thiazides and thiazide related diuretics (chlorthalidone and indapamide), over the alternatives in the

\begin{tabular}{l} 
Table 2 Side effects related to the use of \\
diuretics \\
\hline General side effects \\
Electrolyte disturbances \\
Hyponatraemia \\
Hypokalaemia \\
Hypomagnesaemia \\
Hypocalciuria \\
Hyperuricaemia \\
Impotence \\
Metabolic alkalosis \\
Perturbation of carbohydrate metabolism \\
Hyperglycaemia \\
Insulin resistance \\
Decreased insulin secretion \\
Non-ketotic hyperosmolar state \\
Lipid abnormalities \\
Increased low density lipoprotein \\
Increased very low density lipoprotein \\
Increased total cholesterol \\
Increased triglycerides \\
Specific side effects \\
Frusemide: ototoxicity \\
Spironolactone: gynaecomastia and galactorrhoea \\
Acetazolamide: metabolic acidosis \\
Potassium sparing diuretics: hyperkalaemia \\
\hline
\end{tabular}

management of hypertension. ${ }^{11}{ }^{12}$ In the large Medical Research Council trial, the treatment arm, consisting of bendrofluazide $2.5 \mathrm{mg}$ with or without a $\beta$-blocker and methyldopa, had a lower incidence of stroke than did the placebo arm. ${ }^{13}$ In the STOP-Hypertension trial, a hydrochlorothiazide and amiloride combination together with $\beta$-blockers led to a 
Table 3 Meta-analysis of randomised placebo controlled clinical trials involving the use of diuretics in hypertension according to first-line treatment strategy (data modified from Psaty BM, Smith NL, Siscovick DS, et a/18)

\begin{tabular}{|c|c|c|c|}
\hline Outcome & No of trials & Events (active/control) & Relative risk $(95 \% \mathrm{Cl})$ \\
\hline \multicolumn{4}{|l|}{ Stroke } \\
\hline Diuretics (high dose) & 9 & $88 / 232$ & 0.49 (0.39 to 0.62$)$ \\
\hline Diuretics (low dose) & 4 & 191/347 & 0.66 (0.55 to 0.78 ) \\
\hline \multicolumn{4}{|l|}{ Coronary heart disease } \\
\hline Diuretics (high dose) & 11 & $211 / 331$ & 0.99 (0.83 to 1.18 ) \\
\hline Diuretics (low dose) & 4 & $215 / 363$ & $0.72(0.61$ to 0.85$)$ \\
\hline \multicolumn{4}{|l|}{ Congestive heart failure } \\
\hline Diuretics (high dose) & 9 & $6 / 35$ & $0.17(0.07$ to 0.41$)$ \\
\hline Diuretics (low dose) & 3 & $81 / 134$ & $0.58(0.44$ to 0.76$)$ \\
\hline \multicolumn{4}{|l|}{ Total mortality* } \\
\hline Diuretics (high dose) & 11 & $224 / 382$ & 0.88 (0.75 to 1.03 ) \\
\hline Diuretics (low dose) & 4 & $514 / 713$ & $0.90(0.81$ to 0.99$)$ \\
\hline \multicolumn{4}{|l|}{ Cardiovascular mortality } \\
\hline Diuretics (high dose) & 11 & $124 / 230$ & 0.78 (0.62 to 0.97$)$ \\
\hline Diuretics (low dose) & 4 & $237 / 390$ & $0.76(0.65$ to 0.89$)$ \\
\hline
\end{tabular}

*The numbers of participants randomised to active treatment and placebo, respectively, were 7768 and 12075 for high dose diuretic therapy, and 4305 and 5116 for low dose diuretic therapy.

reduction in cardiovascular mortality and stroke. ${ }^{14}$ In another study in elderly patients, a hydrochlorothiazide and amiloride combination was the only drug that reduced the mortality and stroke morbidity relative to the control group..$^{15}$ In the systolic hypertension in the elderly programme, low dose chlorthalidone with or without other antihypertensive agents led to a $33 \%$ reduction in all strokes compared with the placebo. ${ }^{16}$

In the more recent "antihypertensive and lipid lowering to prevent heart attack trial", the thiazide related diuretic chlorthalidone was shown to reduce cardiovascular events by as much as did angiotensin converting enzyme (ACE) inhibitors and calcium channel blockers in patients with hypertension. ${ }^{17}$ This landmark trial, which studied 33357 people aged 55 years and older with hypertension and at least one other risk factor for coronary heart disease, has been described as one of the most important trials of antihypertensive treatment directly comparing different classes of antihypertensives. It randomised the study participants to one of four antihypertensive regimens: the thiazide diuretic chlorthalidone $(12.5-25 \mathrm{mg}$ a day; $\mathrm{n}=15255)$; the ACE inhibitor lisinopril (10-40 mg a day; $\mathrm{n}=9054)$; the calcium channel blocker amlodipine $(2.5-10 \mathrm{mg}$ a day; $\mathrm{n}=9048)$; and doxazosin (stopped early because of increased mortality). There was no difference in the primary outcome of combined fatal coronary heart disease and non-fatal myocardial infarction between the first three antihypertensives. Fatal coronary heart disease or non-fatal myocardial infarction occurred in $11.5 \%$ of patients treated with chlorthalidone over six years, $11.4 \%$ of those given lisinopril (relative risk compared with chlorthalidone of $0.99 ; 95 \%$ confidence interval (CI) 0.91 to 1.08 ), and $11.3 \%$ of those in the amlodipine group (relative risk compared with chlorthalidone of $0.98 ; 95 \%$ CI 0.90 to 1.07). Causes of mortality were also similar in all three groups. Further results showed that chlorthalidone was more effective than amlodipine by about $25 \%$ in preventing heart failure. Patients treated with lisinopril showed higher six year rates of combined cardiovascular disease, stroke, and heart failure than those given chlorthalidone. All three drugs reduced blood pressure substantially, but systolic blood pressures at five years were significantly higher in the groups taking amlodipine $(0.8 \mathrm{~mm} \mathrm{Hg}$ higher, $\mathrm{p}=0.03)$ and lisinopril $(2 \mathrm{~mm} \mathrm{Hg}$ higher, $\mathrm{p}<0.001$ ) than in the group taking chlorthalidone; the five year diastolic blood pressure was significantly lower in the group taking amlodipine $(0.8 \mathrm{~mm} \mathrm{Hg}$ lower, $\mathrm{p}<0.001)$. Tolerability was generally similar for the three drugs.
A meta-analysis of 18 long term randomised trials comparing diuretics and $\beta$-blockers with placebos showed that the treatment was significantly more effective than the placebo in preventing stroke, heart failure, ischaemic heart disease, and mortality (table 3$).{ }^{18}$ High dose diuretic therapy was shown to reduce the incidences of stroke (relative risk of $0.49 ; 95 \%$ CI 0.39 to 0.62 ) and congestive heart failure (relative risk of $0.17 ; 95 \%$ CI 0.07 to 0.41 ). Low dose diuretic therapy not only prevented stroke (relative risk of 0.66 ; $95 \%$ CI 0.55 to 0.78 ) and congestive heart failure (relative risk of $0.58 ; 95 \%$ CI 0.44 to 0.76 ) but also reduced coronary disease (relative risk of $0.72 ; 95 \%$ CI 0.61 to 0.85 ) and total mortality (relative risk of $0.90 ; 95 \%$ CI 0.81 to 0.99 ).

Another thiazide related diuretic, indapamide, was shown to be better than enalapril in causing regression of left ventricular hypertrophy in the LIVE (Left ventricular hypertrophy regression, Indapamide Versus Enalapril) study. ${ }^{19}$ In the recent "perindopril protection against recurrent stroke" study, a therapy designed to lower blood pressure, consisting of perindopril and indapamide, reduced the risk of stroke in both hypertensive and non-hypertensive individuals with a history of stroke or transient ischaemic attack. ${ }^{20}$

\section{Clinical aspects}

Most patients with mild to moderate hypertension and no renal impairment respond well to lower doses of the various diuretics. ${ }^{21}$ Larger doses have some additional antihypertensive effect, but this is achieved at the cost of increased metabolic and biochemical abnormalities. For uncomplicated hypertension, a moderately long acting thiazide is a logical choice (table 3 ). ${ }^{22}$ In patients with renal failure, defined as a creatinine clearance of less than $25 \mathrm{ml} / \mathrm{min}$, thiazides are usually not effective, and repeated daily doses of frusemide, one or two daily doses of torseamide, or a single daily dose of metolazone is needed. ${ }^{23}$

The antihypertensive effect of the diuretic persists indefinitely, although it may be overwhelmed if the dietary sodium intake exceeds $8 \mathrm{~g}$ /day. ${ }^{24}$ With continuous diuretic therapy, blood pressure usually falls by around $10 \mathrm{~mm} \mathrm{Hg}$, although this depends on various factors, including the initial blood pressure, the quantity of sodium ingested, the adequacy of renal function, and the intensity of the counter-regulatory renin-aldosterone response. ${ }^{21}$

Without a concomitant diuretic, antihypertensive drugs that do not block the renin-aldosterone mechanism may cause sodium retention. Drugs that inhibit the reninaldosterone mechanism, such as ACE inhibitors, and drugs 
Table 4 Commonly used thiazide diuretics and combination preparations available in the United Kingdom (adapted from British National Formulary 45, March 2003)

\begin{tabular}{l}
\hline Used alone \\
Bendrofluazide (non-proprietary) \\
Chlorthalidone (Hygroton) \\
Cyclopenthiazide (non-proprietary) \\
Combination with K sparing diuretics \\
Co-amilozide (amiloride-hydrochlorothiazide) (non- \\
proprietary) \\
Co-triamterzide (triamterene-hydrochlorothiazide) (non- \\
proprietary) \\
Dyazide (triamterene-hydrochlorothiazide) \\
Dytide (triamterene-benzthiazide) \\
Kalspare (triamterene-chlorthalidone) \\
Co-flumactone (spironolactone-hydroflumethiazide) (non- \\
proprietary) \\
Combination with potassium \\
Centyl K (bendrofluazide-potassium) \\
Neo-NaClex-K (bendrofluazide-potassium) \\
Combination with $\beta$-blockers \\
Inderetic (propranolol-bendrofluazide) \\
Inderex (propranolol-bendrofluazide) \\
Co-tenidone (atenolol-chlorthalidone) (non-proprietary) \\
Kalten (atenolol-hydrochlorothiazide) \\
Tenben (atenolol-bendrofluazide) \\
Tenoret (atenolol-chlorthalidone) \\
Tenoretic (atenolol-chlorthalidone) \\
Monozide (bisoprolol-hydrochlorothiazide) \\
Co-Betaloc (metoprolol-hydrochlorothiazide) \\
Co-Betaloc SA (metoprolol-hydrochlorothiazide) \\
Corgaretic (nadolol-bendrofluazide) \\
Trasidrex (oxprenolol-cyclopenthiazide) \\
Moducren (timolol-hydrochlorothiazide-amiloride) \\
Prestim (timolol-bendrofluazide) \\
Combination with ACE inhibitors/ARB \\
Co-zidocapt (captopril-hydrochlorothiazide) non- \\
proprietary \\
Capozide (captopril-hydrochlorothiazide) \\
Innozide (enalapril-hydrochlorothiazide) \\
Carace plus (lisinopril-hydrochlorothiazide) \\
Zestoretic (lisinopril-hydrochlorothiazide) \\
Coversyl plus (perindopril-indapamide) \\
Accuretic (quinapril-hydrochlorothiazide) \\
CoAprovel (irbesartan-hydrochlorothiazide) \\
\end{tabular}

that induce some natriuresis themselves, such as calcium antagonists, may continue to work without the need for concomitant diuretics. However, a diuretic enhances the effectiveness of other types of drugs, including calcium antagonists. ${ }^{425}$

\section{HOW TO USE DIURETICS EFFECTIVELY IN HYPERTENSION \\ Thiazide diuretics}

Thiazides are the most commonly used diuretic agents in the treatment of hypertension. They are recommended as the first line therapy in mild to moderate hypertension in many patients, particularly elderly and black patients. Thiazide diuretics, owing to their slower, longer, and relatively less powerful pharmacological action, are preferred to loop diuretics, which have more acute and short term effects. However, it is several weeks before their antihypertensive effect is noted. Their effect is maximal when smaller doses are used (see table 1). ${ }^{6}$ Thiazide diuretics are much more effective when combined with moderate sodium restriction. ${ }^{24}$ The response rate to thiazide monotherapy in hypertension is variable. The response depends on various factors, including the patient's age, race, and renal function. Instead of increasing the dose of the drug (which may cause significant biochemical abnormalities), another agent should be added if improved control of blood pressure is desired.

Thiazide diuretics are commonly combined with other antihypertensive agents in the treatment of moderate to severe hypertension. Even lower doses-that is, $6.25 \mathrm{mg}$ of hydrochlorothiazide or $1.25 \mathrm{mg}$ of bendrofluazide-may be adequate when thiazides are combined with other drugs. ${ }^{4}$ The usual combination is with $\beta$-blockers. However, preparations consisting of low dose thiazides and ACE inhibitors, angiotensin receptor blockers, and potassium sparing agents are widely used (see table 4).

\section{Thiazide related diuretics}

Chlorthalidone and indapamide are the commonly used thiazide related agents for the management of hypertension. Chlorthalidone has been shown to be safe and effective at lower doses. Indapamide, in smaller doses, seldom disturbs lipid or glucose levels. ${ }^{26}$ Its recently launched slow release form has been shown to have minimal diuretic action with moderate antihypertensive action exerted mainly through its vasodilatory properties. It has also been shown to have class I and class III antiarrhythmic effects. It has a long half life and effectively lowers the blood pressure over 24 hours. Overall, however, indapamide has little advantage over other well tried diuretics. There are also no strict comparisons with low dose thiazides in terms of the effects on glucose tolerance. In general, its side effects profile probably resembles that of the thiazides. Hence, in larger doses, indapamide can cause significant biochemical and metabolic abnormalities similar to those experienced with thiazides. The other diuretic in this group, metolazone, may be effective in patients with renal

\section{Key points}

- Diuretics are useful antihypertensive agents, and there is compelling evidence for their efficacy in patients with heart failure, elderly patients, patients with isolated systolic hypertension, and black patients.

- Low dose thiazide diuretics are the most cost effective agents in mild to moderate hypertension.

- Loop diuretics should be reserved for patients with renal impairment or heart failure.

- The antihypertensive effect of diuretics may be lessened if the sodium intake is more than $8 \mathrm{~g} /$ day; hence, dietary sodium should be restricted.

- Diuretics enhance the effectiveness of other classes of antihypertensive agents when used in combination.

- Start with low doses and gradually titrate to the optimal dose if indicated.

- Diuretics may cause significant impotence, and, therefore, their use should be carefully reviewed in sexually active patients.

- Diuretics should be avoided in patients with a history of gout.

- Diuretics are generally safe in patients with diabetes. However, in brittle diabetes, alternative antihypertensive agents may be used.

- Low dose diuretics seldom cause any significant dyslipidaemia.

- Non-steroidal anti-inflammatory drugs and steroids can blunt the effect of diuretics, and, therefore, their concomitant use should be avoided. 
Table 5 Demographic and haemodynamic clusterings of relative responsiveness to monotherapy according to antihypertensive drug class (modified from Dzau ${ }^{30}$ )

\begin{tabular}{llllll}
\hline Factor & Diuretics & $\beta$-Blockers & $\alpha_{1}$-Blockers & ACE inhibitors or All receptor antagonists & Calcium antagonists \\
\hline Age (older $v$ younger) & ++ & + & ++ & ++ & +++ \\
Race (black $v$ white) & +++ & + & ++ & ++ & +++ \\
Volume dependency $(v$ not) & +++ & + & ++ & + & ++ \\
Renin (high $v$ low) & + & +++ & + & ++ & + \\
Sympathetic activity (high $v$ low) & + & +++ & +++ & ++ & ++ \\
\hline
\end{tabular}

All, angiotensin II; ACE, angiotensin converting enzyme; +, less effective than comparison group; ++, as effective as comparison group; +++, more effective than comparison group.

insufficiency. However, it is a potent diuretic and can therefore cause significant diuresis. Hence, it is rarely used as an antihypertensive agent.

\section{Loop diuretics}

Loop diuretics are potent diuretics but have no more antihypertensive effect than the thiazides. Once daily dosing produces an intense polyuria over a few hours with consequent rebound activation of the compensatory mechanisms and restoration of the haemodynamics to the previous level. Hence, loop diuretics should be used in smaller twice daily doses for more persistent action (table 1). They are particularly useful in patients with coexistent renal or heart failure, in whom thiazide diuretics are rarely effective.

\section{Potassium sparing diuretics}

Potassium sparing diuretics are rarely used alone because they are weak antihypertensive agents. They are usually used in combination with thiazide or loop diuretics to prevent hypokalaemia. However, spironolactone may be effective alone in the treatment of primary or secondary hyperaldosteronism. It is a logical therapy in patients who develop hypertension in the presence of high mineralocorticoid levels during prednisolone therapy and in hypertensive patients with high aldosterone-renin ratios.

The use of diuretics in hypertension is now well established and justified. The recommendations from the Joint National Committee on Hypertension, the World Health Organization International Society of Hypertension, and the British Hypertension Society clearly support low dose thiazide diuretics as the first line therapy in many patient groups. ${ }^{27-29}$ These diuretics are generally safe with few absolute contraindications. Recent work has also helped to resolve the issue of whether to use diuretics in preference to other antihypertensive agents. ${ }^{17}$ There is now compelling evidence for using low dose diuretic therapy in patients with isolated systolic hypertension and in patients with type 2 diabetes mellitus. This therapy has also been shown to be more effective in black patients and in those with volume dependent hypertension (table 5). ${ }^{30}$ Although there are no specific data on the cost effectiveness of individual antihypertensive agents, diuretics are probably more cost effective than more expensive alternatives. ${ }^{17} 31$ Considering all these aspects, low dose diuretics should therefore be used as both first and second line antihypertensive agents in the majority of patient groups.

\section{Authors' affiliations}

S U Shah, University of Birmingham, Birmingham, UK

S Anjum, Glan Clwyd Hospital, Rhyl, Denbighshire, UK

W A Littler, University Hospital Birmingham, Birmingham, UK

\section{REFERENCES}

1 Weir MR, Flack JM, Applegate WB. Tolerability, safety, and quality of life and hypertensive therapy: the case for low-dose diuretics. Am J Med

1996;101:83S-92S.
2 Puschett JB. Diuretics and the therapy of hypertension. Am J Med Sci 2000;319:1-9.

3 Materson BJ, Reda DJ, Cushman WC. Department of Veterans Affairs singledrug therapy of hypertension study. Revised figures and new data. Am J Hypertens 1995;8:189-92.

4 Frishman WH, Bryzinski BS, Coulson LR, et al. A multifactorial trial design to assess combination therapy in hypertension: treatment with bisoprolol and hydrochlorothiazide. Arch Intern Med 1994;154:1461-8.

5 Opie LH, Gersh BJ. Diuretics. Drugs for the heart. 5th Ed. Philadelphia: WB Saunders, 2001:84-106.

6 Kaplan NM. Diuretics as a basis of antihypertensive therapy: an overview. Drugs 2000;59(suppl 2):21-5.

7 Brater DC. Pharmacology of diuretics. Am J Med Sci 2000;319:38-50.

8 Greenberg S, McGowan C, Xie J, et al. Selective pulmonary and venous smooth muscle relaxation by furosemide: a comparison with morphine. $J$ Pharmacol Exp Ther 1994;270:1077-85.

9 Wiemer G, Fink E, Linz W, et al. Furosemide enhances the release of endothelial kinins, nitric oxide and prostacyclin. J Pharmacol Exp Ther 1994;271:1611-15.

10 Pickkers $P$, Hughes $A D$, Frans $G$, et al. Thiazide-induced vasodilation in humans is mediated by potassium channel activation. Hypertension 1998;32:1071-6.

11 Collins R, Peto R, MacMahon S, et al. Blood pressure, stroke, and coronary heart disease. II. Short-term reductions in blood pressure: overview of randomized drug trials in their epidemiological context. Lancet 1990;335:827-38.

12 Hebert PR, Moser M, Mayer J, et al. Recent evidence on drug therapy of mild to moderate hypertension and decreased risk of coronary heart disease. Arch Intern Med 1993;153:578-81.

13 Medical Research Council Working Party. Trial of treatment of hypertension in older adults: principal results. BMJ 1992;304:405-12.

14 Dahl of B, Lindholm LH, Hansson L. Morbidity and mortality in the Swedish trial in old patients with hypertension (STOP-Hypertension). Lancet 1991;338:1281-5.

15 Staessen JA, Ragard R, Thiis L, et al. Randomised double-blind comparison of placebo and active treatment for older patients with isolated systolic hypertension. Lancet 1997;350:757-64.

16 SHEP Cooperative Research Group. Prevention of stroke by antihypertension drug treatment in older persons with isolated systolic hypertension. Final results of the Systolic Hypertension in the Elderly Program (SHEP). JAMA 1991; 265:3255-64.

17 The ALLHAT Officers and Coordinators for the ALLHAT Collaborative Research Group. Major outcomes in high-risk hypertensive patients randomized to angiotensin-converting enzyme inhibitor or calcium channel blocker vs diuretic: the antihypertensive and lipid lowering treatment to prevent heart attack trial (ALLHAT). JAMA 2002;288:2981-97.

18 Psaty BM, Smith NL, Siscovick DS, et al. Health outcomes associated with antihypertensive therapies used as first-line agents. JAMA 1997;277:739-45.

19 Gosse P, Dubourg O, Guret P, et al. Regression of left ventricular hypertrophy in hypertensive patients treated with indapamide SR 1.5 versus enalapril 20 : results of LIVE study. J Am Coll Cardiol 1999:35:346A.

20 PROGRESS Collaborative Group. Randomised trial of a perindopril-based blood-pressure-lowering regimen among 6,105 individuals with previous stroke or transient ischaemic attack. Lancet 2001;358:1033-41.

21 Reyes AJ, Taylor SH. Diuretics in cardiovascular therapy: the new clinicopharmacological bases that matter. Cardiovasc Drugs Ther 1999;13:371-98.

22 Brater DC. Diuretic therapy. N Engl J Med, 1998;339;387-95.

23 Kaplan NM. Southwestern Internal Medicine Conference: difficult to treat hypertension. Am J Med Sci 1995;309:339-46.

24 Singer DRJ, Markandu ND, Sugden AL, et al. Sodium restriction in hypertensive patients treated with a converting enzyme inhibitor and a thiazide. Hypertension 1991:17:798-803.

25 Burris JF, Weir MR, Oparil S, et al. An assessment of diltiazem and hydrochlorothiazide in hypertension. Application of factorial trial design to a multicenter clinical trial of combination therapy. JAMA 1990;263:1507-12.

26 Ambrosioni E, Safar M, Degaute J-P, et al. Low-dose antihypertensive therapy with $1.5 \mathrm{mg}$ sustained-release indapamide: results of randomised doubleblind controlled studies. J Hypertens 1998;16:1677-84.

27 Joint National Committee on Prevention, Detection, Evaluation and Treatment of High Blood Pressure. The sixth report of the Joint National Committee on Prevention, Detection, Evaluation and Treatment of High Blood Pressure. Arch Intern Med 1997;157:2413-46. 
28 Guidelines Subcommittee. 1999 World Health Organization-International Society of Hypertension guidelines for the management of hypertension. J Hypertens 1999;17:151-83.

29 Ramsay LE, Williams B, Johnston DG, et al. British Hypertension Society guidelines for hypertension management 1999: a summary. BM 1999:319:630-5.
30 Dzau VJ. Evolution of the clinical management of hypertension: emerging role of "specific" vasodilators as initial therapy. Am J Med 1987;82:36-43.

31 Pearce KA, Furberg CD, Psaty BM, et al. Comparative cost effectiveness of first line drugs for uncomplicated hypertension. Am J Hypertens $1998: 11: 618-29$

\section{IMAGES IN MEDICINE}

\section{"Tombstone" ST segment elevation of acute myocardial infarction}

A

n 82 year old hypertensive woman presented to the emergency department with a two hour history of retrosternal chest pain. She had no previous history of angina or myocardial infarction. Her initial 12 lead electrocardiogram (ECG) showed massive "tombstone" ST elevation in the anterolateral leads (fig 1) and she was thrombolysed with tenecteplase. She developed torsades de pointes during reperfusion but otherwise made an unremarkable recovery (fig 2 ). She had a troponin $\mathrm{T}$ rise of $6.5 \mathrm{ng} / \mathrm{l}$.

Tombstone ST elevation is an unusual morphological ECG appearance of acute myocardial infarction. The ST segment is convexed upwards and the peak of the convexed ST segment is often higher than the preceding $\mathrm{R}$ wave, which is less than $0.04 \mathrm{~s}$ and small in amplitude. This type of tombstone pattern is associated with reperfusion polymorphous ventricular tachyarrhythmias $^{1}$ and is thought to represent extensive and rapid myocardial damage after the ischaemic episode. At coronary angiography, patients with tombstoning are likely to have high grade stenosis of the proximal left anterior descending artery. ${ }^{2}$

M K Sinha, D Dasgupta, J P Lyons Department of Cardiology, East Surrey Hospital, Canada Avenue, Redhill, Surrey RH1 5RH, UK; msinha@sghms.ac.uk

\section{REFERENCES}

1 Birnbaum Y, Sclarvosky S, Ben-Ami R, et al. Polymorphous ventricular tachycardia early after acute myocardial infarction. Am J Cardio 1993;71:745-9.

2 Guo XH, Yap YG, Chen $\sqcup$, et al. Correlation of coronary angiography with "tombstoning" electrocardiographic pattern in patients after acute myocardial infarction. Clin Cardiol 2000;23:347-52

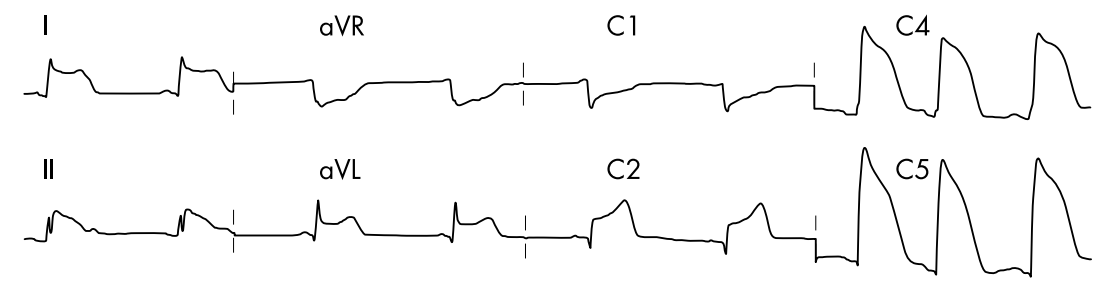

$\begin{array}{llll}\text { III } & \text { aVF } & \text { C3 } & \text { C6 }\end{array}$

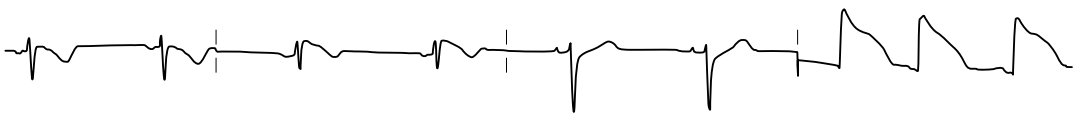

II

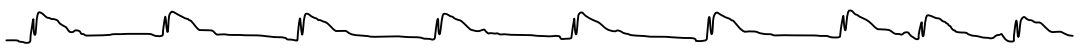

Figure 1 ECG before thrombolysis.
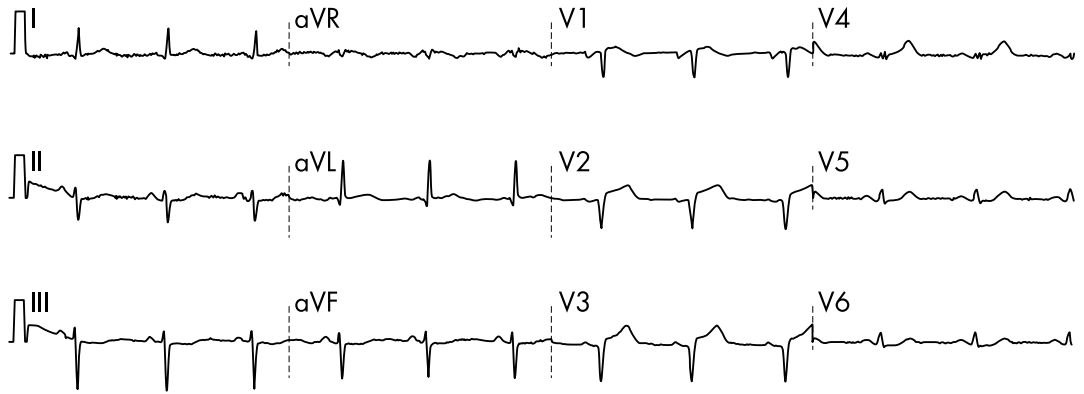

Figure 2 ECG after thrombolysis. 